\title{
IMPROVING THE STUDENTS' SPEAKING ABILITY THROUGH SILENT WAY METHOD AT SMU NEGERI 12 MAKASSAR
}

\author{
${ }^{1}$ Hasria Riski S, ${ }^{2}$ Fathu Rahman, ${ }^{3}$ Andjarwati Sadik \\ ${ }^{1}$ Program Studi Linguistik, Fakultas Ilmu Budaya, Universitas Hasanuddin, Makassar \\ ${ }^{2}$ Program Studi Bahasa Inggris, Fakultas Ilmu Budaya, Universitas Hasanuddin, Makassar \\ ${ }^{3}$ Program Studi Bahasa Inggris, Fakultas Ilmu Budaya, Universitas Hasanuddin, Makassar \\ hasriariski13@gmail.com \\ fathu.rahman@unhas.ac.id \\ andjarck@yahoo.com
}

\begin{abstract}
This research aimed (1) to explore whether or not the use of Silent Way Method can improve the students' speaking ability, (2) to disclose how effective is Silent Way Method in improving students' speaking ability. The research applied the experimental design and the samples comprised 30 tenth grade students of SMU Negeri 12 Makassar divided into two groups namely experimental class consisted 15 students class X IPA 3 and control class consisted 15 students class X IPS 3. The data were collected by using two types of instruments: the speaking test and the questionnaires. The data on the students' speaking ability were analyzed using the descriptive statistics, and the data on the students' questionnaire toward the use of Silent Way Method were analyzed using Likert Scale. The research results revealed that (1) the use of Silent Way Method in teaching speaking had improved the students' speaking ability; and that (2) the students' responses toward the use of Silent Way Method were positive. In fact, the students stated that they found the teaching of speaking more interesting when the Silent Way Method was used to teach them speaking. Thus, the Silent Way Method was effective in improving the students' English speaking ability; the students also found the method much more interesting when used to teach speaking.

Keywords: Speaking, Silent Way Method, Rod
\end{abstract}

\section{A. INTRODUCTION}

Nowadays, in learning the second or foreign language, there are four basic skills that need to be mastered: listening, speaking, reading, and writing. Students should be able to use the skills whether in oral or written form. To achieve the goals, teachers have to teach the language skills to their students and improve their English abilities. It is expected that finally, they are able to communicate effectively, orally as well in written form. In other words, mastering speaking skill is very important in learning a language.

Speaking is the ability to express opinion, ideas, or thought orally; it consists of producing systematic verbal, utterances to convey meaning in order to be understood by the people we are speaking with. Yet, "Celce and Olshtain (2000:165) stated that speaking considers the most difficult skill to acquire since it requires command of both listening comprehension and speech production sub-skills. So, it proves that English is really difficult for students. Speaking is important because people know a language is referred "the speakers" of the language. Many language learners regard speaking ability as the measure of knowing a language. That is why the main purpose of language learning is to develop proficiency in speaking and communicate efficiently. They regard speaking as the most important skill they 


\section{4 | JURNAL ILMU BUDAYA}

can acquire and asses their progress in terms of their accomplishments in spoken communication.

Based on the previous information, it can be said that learning speaking is important and it is found difficult, therefore, teaching speaking needs some teaching methods. In English, there are a number of teaching methods that can improve speaking ability. One of the teaching methods that the researcher wants to research on is Silent Way. In Silent way method, teaching learning is facilitated if the students learn based on the selfcorrection. Therefore, this will make students independent, autonomous, and responsible. In this technique, teachers have to make the students rely on themselves. The students can produce any sound and the teacher will never ask anybody else to do it for them. So, the students are expected to be responsible for the words or utterances they are saying.

There are a number of research have been conducted related to silent way method. One research conducted by Syai'un (2015) entitled "Improving Students' Speaking Ability: the Use of Silent Way." Her subjects were 27 of second grade students of SMU Muhammadiyah 2 Wuluhan, class XI IPA, in the 2014/2015 academic year. Her findings indicated that the silent way method is able to improve the students' speaking ability.

Another research by Prihatini (2014). Her research also used silent way in teaching English in PIA English Course, Manado, entitled "Penggunaan Metode Silent Way dalam Pengajaran Bahasa Inggris di PIA English Course." The sample was 10 students from different junior high schools in Manado. Her findings revealed that the students are more confident in expressing their questions and statements.

Susanti (2015) conducted a
research on "Improving Students'
Vocabulary Using Silent Way Method in

Narrative Text." Her subjects of the research were the eighth grade students which consisted of 30 students. Her findings indicated that there were some improvements in the students' vocabulary by using silent way method. The students got better score in English lesson. The classroom became alive and the students were active during the lesson.

From the findings above, it is clear that silent way contributes significantly in improving students' speaking ability. In this research, the researcher will also apply of silent way in improving students' speaking ability.

What makes this current research is different from the previously mentioned research is that, the use of Rod to improve the students' speaking ability. Next, the title of this research is "Improving the Students' Speaking Ability through Silent Way Method at SMU Negeri 12 Makassar."

This research is important to conduct because the students lack of speaking ability and they are not confident in expressing their ideas orally. This information was obtained from their three English teachers when the researcher had preliminary visit and observation at the school.

In Addition, another problem comes from the teachers who are still using traditional method in teaching speaking, so automatically the students will not be active in the classroom. As we know that using traditional method or conventional teaching where the teacher is the center of knowledge, tends to lead the students not active (passive).

Based on the researcher's observation at SMU Negeri 12 Makassar, as stated in the background, the researcher concluded that speaking ability of the first grade students of SMU Negeri 12 Makassar was still low. So that the researcher want to know how does Silent Way Method improve speaking ability of the first grade students of SMU Negeri 12 


\section{5 | JURNAL ILMU BUDAYA}

Makassar and how effective is Silent Way Method in improving speaking ability of the first grade students of SMU Negeri 12 Makassar. The objectives of this research are to explore whether or not the use of Silent Way Method can improve speaking ability of the first grade of SMU Negeri 12 Makassar and to disclose how effective is Silent Way Method in improving students' speaking ability of the first grade of SMU Negeri 12 Makassar.

\section{B. RESEARCH METHOD}

\section{Research Design}

This research applied experimental design by using two groups namely: an experimental group and a control group. The two groups were treated the same, except for the experimental group. The experimental group received a treatment, namely Silent Way Method.

\section{Population and Sample}

The researcher took the population and sample to make easier way to do the research. In this case, the population of this research was all of the first grade students of SMUN 12 Makassar. The total number of the first grade students are 270 students who are distributed into nine classes (30 students / class).

The number of population in this research was 270 students as mentioned previously. The way the researcher selected the sample was under the direction of the school teacher. She suggested class X IPA 3 and X IPS 3 as the sample of the research. The researcher also used cluster random sampling technique which means only fifteen students were taken as the sample in one class. Class X IPA 3 was taken as the experimental group and class X IPS 3 was taken as the control group. The students of class X IPA 3 is more intelligent than the students of class X IPS 3 . Therefore, class $\mathrm{X}$ IPA 3 is taken as the experimental group.

\section{Instrument and Procedure of Collecting the Data}

To get empirical data and draw the conclusion or the result of the research, the researcher used some instruments and procedures. The instruments and procedures were the measurement tool in the test, which potentially made the researcher easier in collecting data and analyzing. The data were collected through the following instruments and procedures:

\section{Pre-test}

The pre-test was given to both of groups (experimental and control), in order to know their prior knowledge. The test was delivered by answering the questions.

2. Treatment

The researcher gave a treatment only to the experimental group. The treatment was a tool named "Rod (Word Chart)." The researcher used silent way method in teaching in order to find out the students' speaking achievement.

\section{Post-test}

After doing the treatment to the experimental group, the researcher conducted a post-test to both groups. The test for pre-test and post-test were same.

\section{Questionnaire}

To know the effectiveness of silent way method in teaching speaking, the researcher gave the questionnaire after conducting the post-test in the procedures of data collection.

5. Observation

Observation is aimed to collect accurate information about how the silent way actually operates in the classroom. In this section, the researcher acted as participant observer where the researcher was involved in leading the students where necessary. The researcher also acted as non-participant observer where she only observed all the phenomenon occurred in the classroom.

\section{Note-taking}

Note-taking (sometimes written as notetaking or note taking) is the practice of recording information captured from 
another source. (https://en.wikipedia.org). By taking notes, the researcher records the essence of the information, freeing their mind from having to recall everything. Therefore, the researcher used note-taking to write all the phenomenon occurred in the classroom.

\section{Technique of Analyzing Data}

1. Speaking Test

The data were collected from the pre-test and post-test about students' achievement, then analyzed by using the following procedures:

a. Scoring the students' result of the test

To obtain the students' speaking score of both pre-test and post-test depend on three aspects of their answer. They are grammar, vocabulary, and interactive communication. Then, to know the students' score on pre- test and post- test by using this formula:

(Depdikbud, 1989)

$$
\text { Score }=\frac{\text { student answer score }}{\text { highest score }} \times 100
$$

b. Classifying the score of the students

The quality of students speaking score based on their answer was measured into seven classifications as in the following:

Table 1. Scoring Classification of Students Speaking Ability

\begin{tabular}{lll}
\hline No & Classification & Score \\
\hline 1 & Excellent & $96-100$ \\
2 & Very good & $86-95$ \\
3 & Good & $76-85$ \\
4 & Fairly good & $66-75$ \\
5 & Fair & $56-65$ \\
6 & Poor & $36-55$ \\
7 & Very poor & $00-35$ (Depdiknas, 2006) \\
\hline
\end{tabular}

c. Calculating the mean score of the students answer by using the following formula:

$$
\begin{array}{cl}
\sum x & \text { Where: } \\
\hline \boldsymbol{x}=--- & \overline{\mathrm{x}}=\text { Mean Score } \\
& \sum \mathrm{x}=\text { The sum of student's score } \\
& \mathrm{n}=\text { Number of students }
\end{array}
$$

(Ridwan, 2003:102)

d. Then the data were analyzed with the following formula:

$$
\begin{aligned}
& \mathrm{P}=\mathrm{Fq} \\
& \begin{array}{r}
\text { questionnaire } \\
\mathrm{N}
\end{array} \\
& \quad \mathrm{fq}=\text { Number of frequency } \\
& \mathrm{N}=\text { Total samples } \\
& \text { (Arikunto, 2006: 239) }
\end{aligned}
$$

e. Questionnaire

The data on questionnaire were analyzed into Likert Scale and then analyzed in percentage to find out the effectiveness of silent way method in teaching speaking. The data on questionnaire were categorized into positive and negative statements scores as shown in the following table:

Table 2. Likert Scale

\begin{tabular}{ll}
\hline Category & Score \\
\hline Strongly agree & 5
\end{tabular}




$\begin{array}{ll}\text { Agree } & 4 \\ \text { Undecided } & 3 \\ \text { Disagree } & 2 \\ \text { Strongly disagree } & 1\end{array}$

(Sugiyono, 2011: 135)

f. The rating scores range from 20 to 100 and the questionnaire employs five categories. So, the choices of the statements were the data and ranged into five categorized as in the following table:

Table 3. The Rating Score of the Questionnaire

\begin{tabular}{ll}
\hline Range & Category \\
\hline $74-100$ & High \\
$58-73$ & Mory high \\
$42-57$ & Low \\
$26-41$ & Very low \\
$10-25$ & (Wanci, 2014: 55)
\end{tabular}

g. Then the data were analyzed with the following formula:

$\mathrm{Fq}$

$\mathrm{P}=$ questionnaire

$\mathrm{N}$

Where: x $100 \%$

$$
\mathrm{P} \quad=
$$

Percentage from

$\mathrm{fq}=$ Number of frequency

$\mathrm{N}=$ Total samples

(Arikunto, 2006: 239)

\section{FINDINGS}

\section{The Students' Speaking Ability Before and After the Treatment}

It explained about the result description of the research through the scoring classification of pre-test and posttest in experimental group and a control group. It also explained the mean score and standard deviation of pre-test and post-test in both groups.

\section{a. The Students' Score in the Experimental Group}

The members in the experimental group are X IPA 3. The students consist of 15 as the sample. In the experimental group, the students are taught speaking ability through Silent Way Method.

\section{Pre-test}

Pre-test are given to the students before treatment. The students' scores of the pretest were classified into same criteria. After calculating the result of the students' speaking test. There are significant results of scores that classified into Fairly good. The scores ranging between $66-75$. On the other hand, only five students are classified into Good that consider the best mark with 80. The rests are Fair and Poor that occupied by three students and scores ranging between 56-65 classified into Fair and 36-55 classified into Poor. The mean score got from the sum of all scores of the students is 71 which is classified into Fairly good.

\section{Post-test}

In this part, the researcher shows the post-test result from the students. The post-test aims to explain level of students' improvement about speaking ability taught by using Silent Way Method. The question which given to the students in the post-test was the same question which was given in the pre-test.

The students' scores of post-test were classified into same criteria. The students' speaking ability increased from the pre-test to the post-test. There are significant results of the scores that classified into Very good and Good. The scores ranging between $86-95$ which is classified into Very good and $76-85$ 


\section{8 | JURNAL ILMU BUDAYA}

which is classified into Good. In contrast, only three students are classified into Fairly good that consider the lowest mark with 67.

The students have improved their speaking ability after taught by using silent Way Method. For example, the highest score in the pre-test is 80 which classified into Good and there are five students get that score while in post-test the highest score is 87 which classified into Very good and there are seven students reach that score.

The researcher concludes that the students' achievement in the students' speaking ability increases in the post-test. The students' achievement is classified into Very good, good, Fairly good, and none of them classified into Excellent, Fair, Poor, and Very Poor. The mean score got from the sum of all scores of students and the sum of student's score is 81 which is classified into Good.

Based on the score description from the pre-test and the post-test above, the students' score achievement in speaking ability before and after giving treatment are different. The post-test scores are higher than the pre-test scores. So, the mean score of the post-test will be higher than the pre-test. It means that the use of Silent Way Method improved the students' speaking ability.

Table 4. The Mean Score of Students' Pre-test and Post-test in speaking ability.

\begin{tabular}{|l|l|l|}
\hline & Pre-Test & Post-test \\
\hline Mean Score & 71 & 81 \\
\hline
\end{tabular}

Table 4 above shows that there were differences scores between the pretest and the post-test in which students' mean score on the pre-test was 71 . Meanwhile, students' mean score on the post-test was 81 . This score shows that there was a higher score on the post-test mean score after giving treatment. It means that the use of Silent Way Method improved the students' speaking ability.

\section{b. The Students' Score in the Control Group}

The members of control group are the students of X IPS 3. The students consist of 15 students as the sample. In the control group, the students were not taught speaking ability through Silent Way Method but the students are taught speaking ability through conventional teaching which is usually done by the teacher at the school. The main data of the control group's scores are collected from the pre-test and the post-test.

\section{a. Pre-test}

Pre-test are given to the students before taught conventional teaching. The students' scores of the pre-test were classified into same criteria. After calculating the result of the students' speaking test. There are significant results of scores that classified into Fairly good. The scores ranging between $66-75$. On the other hand, only five students are classified into Good that consider the best mark with 80 . Two students get score 60 which is classified into Fair, one student get score that is classified into Poor that consider with 47 , and one student get score 27 which is classified into Very poor. The mean score get from the sum of all scores of the students is 67 which classified into Fairly good.

\section{b. Post-test}

The researcher shows the post-test result from the students. The post-test aims to explain level of students' improvement about speaking ability taught by using conventional teaching. The question which given to the students in the post-test was the same question which was given in the pre-test.

The students' scores of post-test were classified into same criteria. The students' speaking ability has not increased from the pre-test to the post-test. There are not significant results of the scores after taught conventional teaching. 
There are only four students get 80 which is classified into Good, seven students get Fairly good, the scores ranging between 66 - 75. One student get 60 which is classified into Fair, two students get 47 which is classified into Poor, and one student get 27 which is classified into Very poor.

The researcher concludes that the students have not improved their speaking ability after taught by using conventional teaching which is usually done by the teacher at the school. The students' achievement is classified into Good, Fairly good, Fair, Poor, Very poor and none of them classified into Excellent and Very good. The mean score got from the sum of all scores of students and the sum of student's score is 65 which classified into Fair.

Based on the score description from the pre-test and the post-test above, the students' score achievement in speaking ability from the pre-test and the post-test are different. The post-test scores are lower than the pre-test scores. So, the mean score of the post-test will be lower than the pre-test. It means that the use of conventional method had not improve the students' speaking ability.

Table 5. The Mean Score of Students' Pre-test and Post-test in speaking ability. test and the post-test in which students' mean score on the pre-test was 67 . Meanwhile, students' mean score on the post-test was 65 . This score shows that there was a lower score on the post-test. It means that the use of conventional method had not improve the students' speaking ability.

\section{c. The Students' Questionnaire}

The questionnaire was distributed to the students after conducting the posttest with respect to know their opinion in terms of using Silent Way Method in teaching speaking.

The questionnaire covered 15 positive statements about the use of silent Way Method in teaching speaking and the students were asked to respond whether they were: strongly agree, agree, undecided, disagree, strongly disagree with the statement. The questionnaire was analyzed based on the percentage of each answer and the researcher analyzed the questionnaire by using Likert Scale measurement in Sugiyono (2011:134). The number frequency was divided to 15 (the number of the total respondents) then multiplied to $100 \%$.

The important thing to be noticed from the statement of the all questionnaires number $1-15$ that all the students gave positive response to the statement above and none of the students chose as negative

\begin{tabular}{|c|c|c|}
\hline & Pre-test & Post-test \\
\hline Mean Score & 67 & 65 \\
\hline
\end{tabular}

response.

Table 5 above shows that there were differences scores between the pre-

Table 6. The Percentage of the Students' Questionnaire

\begin{tabular}{|cc|c|c|c|}
\hline \multirow{2}{*}{ Interval Score } & \multirow{2}{*}{ Category } & \multicolumn{2}{c|}{ Silent Way Method } \\
\cline { 3 - 5 } & & F & \% \\
\hline $74-100$ & 5 & Very high & 8 & 53 \\
\hline $58-73$ & 4 & High & 7 & 47 \\
\hline $42-57$ & 3 & Moderate & 0 & 0 \\
\hline $26-41$ & 2 & Low & 0 & 0 \\
\hline $10-25$ & 1 & Very low & 0 & 0 \\
\hline & & Total & 15 & 100 \\
\hline
\end{tabular}


Table 6 is about students' interval scores of questionnaire and it presented that there were $8(53 \%)$ of the students felt strongly positive, $7(47 \%)$ of the students felt positive and none of the students felt neutral, negative, and strongly negative respectively.

Furthermore, the mean score of students' questionnaire toward the use of Silent Way Method was 72.2 which is categorized into High. The students' questionnaire scores can be seen in the following table:

Table 7 The Mean Score of the Students' Questionnaire.

\begin{tabular}{|l|c|}
\hline \multirow{2}{*}{ Silent Way Method } & Mean Score \\
\cline { 2 - 2 } & 72.2 \\
\hline
\end{tabular}

\section{DISCUSSION}

There are some researchers have conducted researches in improving speaking ability through Silent Way Method. From all the researchers that have been explained in the previous chapter, the researcher is able to assume that the method which was used by them in doing their researches was effective in improving the students' speaking ability. The result of their researches revealed that all the methods used by the researchers above improved the students' speaking ability.

The result of this research revealed the same report with the previous researchers that the use of Silent Way Method improved the students speaking ability moreover it improved the students' speaking ability in experimental group and the positive comments that have been given by the students toward the use of Silent Way Method.

\section{The Students' Speaking Ability}

The purposes of this research were to find out whether or not the use of Silent Way Method can improve the students' speaking ability and to disclose how effective is Silent Way Method in improving students' speaking ability. The comparison of the pre-test and the post-test by applying statistical analysis as has been explained in the previous chapter. It revealed that there is significant difference between the pre-test and the post-test score, the score of the post-test is higher than the score of the pre-test in the experimental group. It means that the use of Silent Way Method in teaching speaking improved the students' speaking ability. The score of the post-test is lower than the score of the pre-test in control group. It means that the use of Conventional Method in teaching speaking had not improve the students' speaking ability.

To know whether the improvement of the students' score is significant or not, it can be seen from the students pre-test and post-test mean score. The students pretest mean score was 71 and it was categorized into fairly good classification, while the students post-test mean score was 81 and it was categorized into good classification. It means that the improvement of the students' speaking ability was significant after getting treatment. It indicated that the use of Silent Way Method improved the students' speaking ability significantly.

\section{The students' Questionnaire}

The analysis showed that the use of Silent Way Method affected significantly to the students' interest in attending the reading class during conducting the treatment. All of the questionnaires are positive statement given by the students, whether it was strongly agree or agree. It means that, this method is including a good method in teaching speaking ability. Mostly the students stated that they were diligent in joining English class since teacher taught by using Silent Way Method. There were $12(80 \%)$ of the students agree that Silent Way Method helps them improve their English skill in speaking. It was also proved by the mean 


\section{1 | JURNAL ILMU BUDAYA}

score of the students' questionnaire was 72.7 which categorized into high. On the other hand, the students' questionnaire is one of the indications of success level toward language skill that they are learning foreign learning setting.

In this research, the students' questionnaire was considered as the result given by the students after conducting treatment by using Silent Way Method in teaching speaking. $10 \quad(67 \%)$ of the students chose that categorized as strongly agree and 15, $5(33 \%)$ of the students agree that they got more opportunities to discuss with their classmate in teaching and learning process especially English subject and for questionnaire number 11, mostly the students strongly agree with that statement that they hope Silent Way Method will be applied in the next semester.

From the result of the students' speaking achievement and the students' questionnaire toward the use of Silent Way Method, it showed that is effective to improve the students' speaking achievement and positive response. It indicated that speaking achievement mean score in the post-test was 81 and it was categorized into good classification, while the mean score of the students' questionnaire 72.7 which categorized into high. It is in line with Cambell and Dickinson in Wanci (2014: 94) said that teachers need to incorporate a variety of strategies so that they reach and successful with more students than they have been in the past. It means that teachers in teaching and learning process should apply variety of strategies, methods, or learning style to create the enjoyable or comfortable setting in learning.

\section{E. CONCLUSION}

Based on the research findings and discussion in the previous chapter, the researcher formulated the conclusions as in the following:
1. The use of Silent Way Method in teaching speaking improved the students' speaking ability in experimental group. The mean score of the pre-test was 71 and it was categorized as fairly good classification, while the students post-test mean score was 81 and it was categorized into good classification. The use of Conventional Teaching in teaching learning had not improve the students' speaking ability in control group. The mean score of the pre-test was 67 and it was categorized as fairly good classification, while the students post-test mean score was 65 and it was categorized into fair classification. From the result above, it indicated that the improvement of the students' speaking ability was significant.

2. Positive comments that have been given by the students toward the use of Silent Way Method in teaching speaking. Table 6 shows that there were $8(53 \%)$ of the students felt strongly positive and 7 (47\%) of the students felt positive toward the use of Silent Way Method. It was also proved by the mean score of students' questionnaire was 72.2 which categorized into high.

Considering the conclusion above, the researcher addresses the following suggestions:

1. It is suggested that teaching speaking ability by using Silent Way Method should be continuously implemented to the students of high school, to the junior high school, and also to all English students since the use of Silent Way Method in teaching speaking could make students speaking ability well.

2. As stated in the scope of this research, the researcher used Silent Way Method in teaching speaking only, but perhaps it will be better if the method of this research could be applied in doing 


\section{2 | JURNAL ILMU BUDAYA}

research for other English skill, such us writing, reading, and listening.

3. The researcher recommended to the next researcher to compare Silent Way Method with the other speaking strategy in doing research, so that, it will be known which one is better in improving students' speaking ability.

\section{BIBLIOGRAPHY}

Arikunto, Suharsimi. 2006. Prosedur Penelitian; Suatu Pendekatan Praktek. Jakarta:PT. Rineka Cipta.

Brown, H. Douglas. 1987. Principles of language learning and teaching. EnglewoodCliffs, New Jersey, Prentice Hall.

Celce, Marianne and Elite Olshtain. 2000. Discourse And Context In Language Teaching. United Kingdom: Cambridge University Press.

Depdiknas. 2006. Pembelajaran Bahasa Inggris. Jakarta: Badan Standar Nasional Penhadikan.

Dirjen Penhadikan Dasar dan Menengah. 2005. Peraturan Directorat Jenderal Penhadikan Dasar dan Menengah Tentang
Penilaian Perkembangan Anak Hadik. Jakarta.Depdikbut.

Gattegno, Caleb. 1972. Teaching foreign languages in schools: the silent way, 2thed. New York: educational Solution:inc.

Https://en.wikipedia.org/wiki/Note-taking Prihatini, Dyah Ayu. 2014. Penggunaan Metode Silent Way Dalam Pengajaran Bahasa Inggris Di PIA English Course Manad. (Manado: Universitas Sam Ratulangi Fakultas Ilmu Budaya Manado.

Ridwan. 2003. Dasar-Dasar Statistika. Bandung. Alfabeta.

Susanti, Dwi Riana. 2015. Improving Students' vocabulary Using Silent Way Method in Narrative Text. Slamet Riyadi University.

Syai'un, Zahro Umilailatul. 2015. Improving Students' Speaking Ability: the Use of Silent Way. Muhammadiyah University of Jember.

Wanci, Riswan. 2014. Improving the Reading Comprehension of the Tenth

Grade Students of SMU. N 12 Makassar Through Know- WantLearn Strategy. Hasanuddin University. 